\title{
Die mittelalterlichen Taufsteine der Provinz Schleswig-Holstein.
}

Hrsg. mit 52 Abbildungen von Dr. Ernst Sa uermann.

B. Nöhring. Lübeck. 1904. 72 s. +1 kort. 8. 0

Sonderjyllands ældre kunsthistorie er i den senere tid bleven behandlet $i$ en række enkeltskildringer af tyske videnskabsmænd. Professor Matthaei har i to, tidligere her i "A arbøgerne" anmeldte værker undersøgt de talrige altertavler og andre kirkelige træskærerarbejder fra middelalderens sidste århundreder, dr. Brandt, direktor for Thaulowmuseet i Kiel, har yderst grundig gjort rede for den betydeligste af det 17 . århs. mange billedskærere, Gudewert, og endelig har nu dr. Sauermann, søn og efterfølger af Flensborgs kunstindustrimuseums afdøde grundlægger, behandlet de middelalderlige døbefonte i Slesvig og Holsten. Lignende arbejder er planlagte for de tre nordiske lande, og det er ret forståeligt, at fontene frister ærkæologer og kunsthistorikere. Først og fremmest fordi de, bortset fra kirkebygningerne, så omtrent er det eneste, der er levnet os af 12-13. århs. romanske kunst. Grunden hertil er selvfolgelig materialet, der bedre end træet har kunnet modsta tidens tand, og 
ikke som malmen eller de ædle metaller har fristet nogen; de svære stenkummer var der såvist ingen, der lob med. I det hojeste kunde de jo bruges som vandtrug eller til dekoration $i$ haverne, og en del er da også vandret den vej, når ivrige præster eller kirkeældste ikke har fundet dem fine nok. En overordentlig stor mængde er dog endnu i behold. Forf. giver ingen statistik, men efter Haupts „Bau u. Kunstdenkmäler" har ikke mindre end ca. 150 af Sønderjyllands ca. 260 kirker deres gamle fonte $\mathrm{i}$ behold. Deres fordeling er ikke uden interesse. I de fem nordligste amter, det egentlige Nord- og Mellemslesvig, er der bevaret ca. 130 på et samlet kirketal af ca. 170, medens Sydslesvig 0: Ekernforde, Slesvig; Ejdersted og Husum amter kun har ca. 20 i 88 kirker. Mod nord er altså godt trefjerdedele, mod syd næppe enfjerdedel oprindelige. Grunden hertil er sikkert den, at man i disse egne, der dels mod vest i Friserne havde en usædvanlig velstånde kefolkning dels talte mange herregårde, ikke i længden har villet lade sig nøje med den romanske kunsts ofte tunge og plumpe former, men delvis allerede $\mathrm{i}$ middelalderens sidste tid har ombyttet dem med mere moderne. Mod nord har man derimod $i$ denne som $i$ anden henseende været mere konservativ $i$ dette ords egentlige betydning.

Bogen er selvfolgelig ikke topografisk ordnet, men fontene deles i forskellige grupper, der behandles hver for sig. Til grund for den forste store klassificering - har forf. lagt materialet, den forskellige stenart, der er anvendt. Thi med rette er de ikke ganske få malmfonte udeladte; de er nemlig for en stor del 
klokkestøberarbejder og lader sig derfor bedst behandle i sammenhæng med kirkeklokkerne. Stenfontene falder ganske naturlig $\mathrm{i}$ to store hovedgrupper, en hjemlig og en fremmed, der behandles forst. Af fremmede stenarter har man pa Vestkysten i ikke ringe grad benyttet en bla marmor eller kalksten fra Namur i Belgien samt en gullig sandsten fra Weseregnen. Den sidste er også bleven brugt til en enkelt kongerigsk font i Ribeegnen samt i domkirken her, fra hvilken mindre stykker har forvildet sig til et par andre sydjydske kirker. Namurstenen findes derimod kun i Sonderjylland langs Vesterhavet oy $i$ en række kirker ved Ejder og Trenen. Enkelte af disse fonte stammer fra 12-13. årh., men storstedelen er yngre, hvad der er nok så interessant, da det viser, at den livlige handelsforbindelse tværs over Vesterhavet, der på Valdemarernes tid bl. a. bragte materiale (rhinsk tuf) til en hel række kirker i Sydrestjylland og Slesvig, har holdt sig meget længe, således at der synes at være direkte forbindelse mellem den ældre middelalder og det 17. århs. forsøg på hollandsk kolonisation.

I en ganske anden retning peger den tredje fremmede stenart, den gullandske kalksten. Og medens fontene fra Namur og Weser kun fandtes $i$ enkelte bestemte egne, er Gullandsfontene spredt over hele landet. Som påvist af forf. forekommer de langs Østersøens sydkyst, og også i kongeriget er de almindelige. Fra Ribeegnen til „Heden “ ved Roskilde, fra Hjorring til Lolland-Falster, høor de er særlig hyppige, træffer man deres sirlig-elegante former. Der ma åbenbart have været en ren storindustri af 
fonte på Gulland, hvis nange prægtige kirker endnu vidner om de gamle "stenmestres" duelighed. Thi at de er bleven udførte fra øen i fuldfærdig stand, er ganske utvirlsomt, ikke blot "højst sandsynligt" sum forf. skriver; alene af de corte beskrivelser i Brunius, "Gotlands Kunsthistoria“ - en bog forf. citerer kan man se, at fonte af ganske sanme art endnu findes $i$ adskillige af øens kirker. $\mathrm{Og}$ at udføre råmaterialet for bagefter at indføre det i forarbejdet stand, vilde unægtelig være at gå over bækken for at hente vand. Om man så har haft et slags depot i Lybæk, der fra anden side er bleven hærdet som deres tilblivelsessted, eller om man har hentet dem på øen selv, ja det er et spørgsmaal for sig. Det skal her blot antydes, at det for Lolland - Falsters vedkommende ligger nærmest at tænke på de store Skånemarkeder i Skanør og Falsterbo.

Medens disse tre arter fonte bærer vidne om de lande, med hvilke vor hjemstavn $i$ de fjærne tider stod $\mathrm{i}$ handelsforbindelse, er den fjerde gruppe af hjemlig herkomst. Ikke blot er materialet indenlandsk - det er den granit, istiden forte med sig fra den skandinaviske halve i form af "kampesten", - men de er også forfærdigede her $i$ landet. Thi medens f. ex. gullandske kalkstensfonte af ganske ens udseende forekommer i Vendsyssels og Meklenborgs kirker, har hver enkelt egn sin mere eller mindre ensartede type af granitfonte, ja mellem flere er ligheden så stor, at de utvivlsomt må være huggede af samme mester eller i samme værksted. Navnlig i Nord- og Mellemslesvig udgør de den langt overvældende mængde, der dog gennem- 
giende lader sig indordne under enkelte hovedformer. Foruden i flere mindre grupper har forf., dels gàende ud fra deres form dels fra deres billedlige udsmykning, inddelt dem $i$ to store hovedgrupper, en astlig og en vestlig, som han søger at sætte $i$ forbindelse med datidens nationale forhold. Det kan endda gå på astkysten, hvor der i 12. årh. endnu boede en „temmelig ren jydlsk befolkning“ (s. 37), derimod er det ham af gode grunde umuligt andetsteds at fastsl£ „en jydsk, frisisk

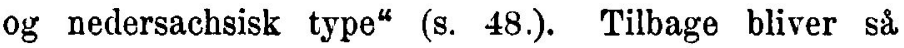
enkelte fonte, der ikke lader sig indordne under nogen bestemt gruppe. Det er i kunstnerisk henseende absolut de mest værdifulde, fonte som Munkbrarups og Førs (fig. 45 og 46) hører trods deres noget ubehjæelpsomme udforelse til den bedste romanske kunst i Sonderjylland; der er over dem en forbarsende kraft og djærvhed. Navnlig overfor dem må man beklage, at forf. har måttet lade sig nøje med de tarvelige tegninger, han giver, så meget mere som de fotografiske ætsninger, der ledsager texten, gennemgående er særdeles gode, flere endog fortrinlige. Ogsa mellem de andre fonte findes adskillige særdeles smukke stykker, f. ex. Grarup (fig. 21), Store Solt (fig. 35), Treja (fig. 36), Skodborg (fig. 48) og Vedsted (fig. 41), men i det hele og store kan de hverken kunstnerisk eller arkæologisk måle sig med deres naboer i Nørrejylland, hvor stenhuggerkunsten i Valdemarernes tid har staet overmåde hojt. I anden henseende har de derimod megen interesse.

I lighed med de ovenfor nævnte værker har forf. behandlet begge hertugdømmerne, altså den prøjsiske provins Slesvigholsten, under ét. Men medens dette 
var en naturlig sag f. ex. for de middelalderlige altertavler, fordi de enten er direkte importerede fra Tyskland (Lybæk) eller skriver sig fra middelalderens slutning, hvor de to landes overklasse ialt væsentlig havde samme kultur, bliver det her ret kunstlet. Døbefontene stammer nemlig fra en tid, da det skæbnessvangre politiske ægteskab endnu ikke var indgået, da Ejjeren både politisk og kulturelt var grænseflod. For at overbevise sig herom behover man blot at kaste et blik - helst ikke red kunstigt lys! - på det meget fortjenstfulde kort, der giver en oversigt over fontenes forskellige materiale. Det er for det forste påfaldende, hvor få gamle fonte, der er bevaret $i$ Holsten, og dernæst vil man se, at den blå streg, der betegner granitfontene, kun træffes under fire holstenske bynavne, medens den i Sonderjylland strækker sig ned til en linje fra Kosel ved Ekernførde over Treja til Ollerup og Fjolde mod vest. Syd for denne linje er de grønne streger (Namurstenen) næsten eneherskende, norden for den er de, blå $i$ alt overvældende flertal, og tænkte man sig kortet forlænget mod nord op til Skagen, vilde den hele halvø være som et blåt blomsterbed. Også stenene kan tale, og hojt og tydeligt vidner de om, fra hvilken side vor landsdels gamle kultur er kommet.

Kun delvis har forf. set dette. Selvfølgelig er han klar over, at grænsen for de forskellige døbefontstyper ikke falder sammen med den politiske grænse, men når han dernæst siger, „hvad nu de slesvigske døbefontstypers videre forhold til de danske angår, kan der ikke være tale om en afhængighed i 
formal henseende", er dette kun rigtig taget rent efter bogstaven. Bag ved ligger en stor misforstäelse, der bunder i manglende kendskab til ældre dansk kunst. Kunsten, hvis man kan bruge dette udtryk om godt gammelt stenhuggerarbejde, or i høj grad lokal, dens udtryk er forskellige ikke blot $i$ landets forskellige provinser, men selv $\mathrm{i}$ disses enkelte egne. Man kan med fulstændig ligeså stor ret sige, at der ikke er nogen forbindelse mellem fontene pa Sjælland og Fyn, ja for blot at tage den førstnæunte o, der i sterrelse jo nogenlunde svarer til hertugdommet, træffer vi p\& den to store hovedformer, mellem bvilke der ikke er fjærneste lighed. Ikke blot i udsmykningen, men hvad der er vigtigere, i hele den ydre form, er der langt storre forskel mellem dem end mellem de to sønderjydske hovedtyper. $O g$ for at gå over til Jylland har vi dér tre, fire store hovedgrupper, af hvilke en enkelt atter spalter sig i henved en halv snes skarpt afgrænsede underarter. Selv på ganske små områder som Lolland og de sydfynske oer iagttages den samme hovedregel: Loven om de stedbundne typer, som man kunde kalde den. Har man forst fảet fat på dette centrale punkt, undrer det én ikke, „at med andre typer vexler i Jylland også ornamentiken og de motiver, der fremstilles" (s. 65). Selvfølgelig er og må der være ulighed, man må blot ikke over den glemme den endnu større lighed, der ligger $i$, at man nord og syd for Kongeåen har holdt sig til den samme udførelsesmåde, de samme hovedformer og det samme materiale, der vel at mærke sá godt som ikke anvendes til døbefonte $i$ Nord- og 
Mellemtyskland (ned undt. af egne i det gamle Nedersachsen), og som ikke dér gøres til genstand for kunstnerisk behandling, medens det af gode grunde næsten er enerådende indenfor Danmarks gamle område, hvor navnlig $\mathbf{i}$ de jydske kvaderstenskirker den hårde granit er bleven behandlet på en måde, der endnu vækker vor beundring. Man kan derfor udmærket godt med forf. i vore gamle fonte se ,t vexlende billede af en hjemlig stenplastik“ (s. 65), blot må man tilfoje, at denne plastik ligeså godt som den jydske, den fynske, den sjællandske og den skånske er $d$ a n sk provinsiel kunst. Til overflod er der en del direkte bereringspunkter mellem de sønderjydske granitfonte og deres naboer mod nord og ost. Forf. gør selv opmærksom pi, at grænsen for en udpræget type går fra Vejlefjord skråt ned til Tonder (s. 63-64), og hertil kan fojes, at der i Vest- og Sydfyn forekommer fonte smykkede med ganske den samme bladranke, som den der findes vesten for Lillebelt. $O g$ en parallel til Munkbrarupfontens fremstilling af løven, der er i færd med at sluge en mand, som gennemborer den med sit sværd, findes udhugget på en fynsk dobefontsfod (Hillerslev ved Fåborg).

Det har nærmest været anmelderens hensigt at gøre opmærksom pa, hvad man i kulturel og national henseende kunde lære af vore gamle debefonte. At give en indgående arkæologisk kritik af forf.s resultater vilde derimod falde udenfor dette tidsskrifts rammer. Bedst lykkedes er ubetinget bogens første afsnit om de indforte fonte, mindre tilfredsstillende er afsnittet om granitfontene og den almindelige del. Fejlen ligger 
her ikke så meget $\mathbf{i}$, hvad der siges, som i, hvad der er udeladt. Forf.s klassificering af de forskellige typer er i det hele rigtig, og i forklaringen af de ofte gådefulde fremstillinger, hvormed fontene er smykkede, holder han sig ganske borte fra de såre fantastiske fortolkninger, i hvilke navnlig den ældre ærkæologi var så stiv. Men man kunde dog nok have onsket en noget storre fylde, at der f. ex. var bleven taget fat på spørgsmålet om forholdet mellem kirkebygningerne og fontene og disses forhold til den ørrige stenskulptur.

Dog anm. ved bedst selv, hvor ulige vanskeligere arkæologen er stillet end historikeren, der i sin stue eller $i$ arkivets læsesal kan samle de kilder, hrorp̊̊ han bygger sin fremstilling, medens der her må udføres et besværligt og ofte kostbart arbejde i marken.

M. Mackeprang. 